\title{
STUDIES ON THE MORNING ALKALINE TIDE OF URINE IN NORMAL PERSONS AND IN PATIENTS WITH NEPHRITIS ${ }^{1}$
}

\author{
By JOHN E. MCCORVIE \\ (From the Mayo Foundation, Rochester, Minnesota)
}

(Received for publication June 22, 1925)

INTRODUCTION

The hydrogen-ion concentration of the urine has been the subject of much interesting study; by both pathologist and clinician, especially since the work of Henderson and Palmer. These investigators, using twenty-four hour specimens, studied the hydrogen-ion concentration of the urine both in normal persons and in patients with various diseases, including nephritis. They found that on the average the urine of nephritics was definitely more acid than that of normal persons. It has long been well-known that in normal individuals the urine is more alkaline during the morning. In 1919, Leathes investigated the changes that took place in the morning specimens in cases of acute and subacute nephritis in soldiers, and found that the alkaline tide, which was always normally present, was sometimes reduced or even absent in nephritis.

As there were such good opportunities at the Mayo Clinic to study cases of nephritis, it seemed important to discover what bearing Leathes' test might have on treatment or prognosis. Studies were accordingly undertaken with this object in view.

\section{METHODS}

The first series of cases was investigated according to a modification of Leathes' technic (table 1). His method of demonstrating the alkaline tide was as follows:

\footnotetext{
${ }^{1}$ Submitted to the Faculty of the Graduate School of the University of Minnesota in partial fulfillment of the requirements for the degree of Master of Science in Medicine, March, 1923.
} 
A night specimen of urine was collected at 7:00 a.m. for the period from 11:00 p.m. to 7:00 a.m., and the second specimen at 8:00 a.m., immediately after which $500 \mathrm{cc}$. of water was given. Hourly specimens were then collected until twelve o'clock. No other fluid or food was taken by the patient after the evening meal preceding the test until its completion. By using suitable indicators, and titrating with tenth-normal acid and tenth-normal alkali, Leathes estimated the alkalinity per cent of the urine. Henderson and Palmer had previously described a similar method for obtaining the ratio of actual to total possible alkali excreted, by titrating with acid and alkali to a known hydrogen-ion concentration. It will be noted that by giving $500 \mathrm{cc}$. of water the ability of the patient to excrete water could be tested, and the range of specific gravity determined. In all the cases described the amount and specific gravity of each specimen was noted.

A series of buffer solutions were made up according to the method of Henderson and Palmer. At a later date these solutions were made up from Clark's tables. The accuracy of the $\mathrm{pH}$ solutions was checked by means of the electro-titration apparatus of Wendt, and in some cases the $\mathrm{pH}$ of the urine was estimated by this means as well as by the colorimetric method. The $\mathrm{pH}$ was estimated in all cases except those in table 1.

In the course of the work it became apparent that the hydrogen-ion concentration of the urine may change soon after it is voided. It has been shown by Gamble, and by Marshall, that on standing or shaking, carbon dioxid is liberated from the urine, and that the resulting change in $\mathrm{pH}$ may be quite marked, especially in the more alkaline urines. It was therefore decided to run a series of urine samples from normal and abnormal cases, estimating the carbon dioxid and phosphrates in addition to the properties mentioned. The phosphates were of particular interest as they are largely responsible for the buffer action of the urine.

The carbon dioxid in the various specimens was estimated by van Slyke's method, and the phosphates by Doisy and Bell's colorimetric method. In this group of cases, all males, every precaution was taken to avoid any loss of carbon dioxid, and the consequent change in hydrogen-ion concentration. The urine in each case was passed by means of a funnel which emptied below a layer of toluene into an especially prepared narrow cylinder. This was at once corked, and, care being taken to avoid any shaking, carried to the laboratory in a neighboring room, where the carbon dioxid was at once estimated and the $\mathrm{pH}$ determined; immediately after this the alkalinity per cent was estimated. The complete study as outlined was carried out in all the normal cases (table 2) and in certain of the abnormal cases included in tables 3 and 4 . The carbon dioxid and phosphate results for both normal and abnormal cases are shown in table 4.

One of the simplest tests for changes in the acid-base equilibrium in the individual was the direct determination of the alkali reserve of the blood plasma by van Slyke's method. It seemed important to determine at the onset whether there were not definite abnormalities in the excretion of acid by the kidneys, with little or no decrease in the carbon dioxid combining power of the blood plasma. Accord- 
ingly, in a group of both normal and abnormal cases, I determined this factor, using samples of blood obtained both before water was given and at the time the diuresis should be at its height (table 7).

\section{RESULTS IN NORMAL CASES}

The minimal excretion from 8:00 a.m. to 12:00 m., after $500 \mathrm{cc}$. of water had been given at 8:00 a.m., was 260 cc., the maximal 1066 cc., and the average $699 \mathrm{cc}$. The minimal specific gravity at the height of diuresis varied from 1.003 to 1.012 , while the maximal varied from 1.024 to 1.035 . The smallest range difference was 0.020 in a case in which the specific gravity varied from 1.012 to 1.032 . The greatest range difference was 0.030 , the specific gravity varying from 1.005 to 1.035 . The average range difference was between 0.024 and 0.025 . The initial alkalinity per cent varied from 21 to 56 , and the maximal from 64 to 96 . In every case there was a definite and unmistakable rise in the alkalinity per cent during the morning, under the conditions of this test. The initial $\mathrm{pH}$ ranged from 5.35 to 6.2 , with an average of 5.65 , the maximal $\mathrm{pH}$ from 5.9 to 7.7 , the average being 6.95. The phosphates always showed a decrease during the morning, the night specimen always containing the maximal amount. Following the early initial decrease there was a definite though slight increase later in the morning, even though the urine became more alkaline.

The results in these normal cases are in accord with those of Leathes, showing in every case a definite diuresis and a definite alkaline tide during the morning. Leathes also performed the test with varying amounts of water, even less than $500 \mathrm{cc}$., and found that the change in the alkalinity per cent still persisted. In one normal case I tried the test without administering water, and obtained a normal curve for the alkalinity per cent, and an increase in the $\mathrm{pH}$ figures as in the other normal cases in which water was given.

The change in the $\mathrm{pH}$ toward the alkaline side during the morning showed a definite but not exact parallelism to the curve of the alkalinity per cent. The carbon dioxid increased relatively with the increase in alkalinity. In every case it was found that a higher $\mathrm{pH}$ figure, that is, a change to the alkaline side, was accompanied by relatively increased carbon dioxid, and correspondingly an increased acidity was always accompanied by a fall in the carbon dioxid. In other words, 
the carbon dioxid always varied directly with the figure of the hydrogen-ion concentration. This is in accord with the work of Gamble and Marshall. The total carbon dioxid naturally does not follow the $\mathrm{pH}$ so strikingly. The decrease in the phosphates during the morning and the later increase correspond to the findings of Fiske.

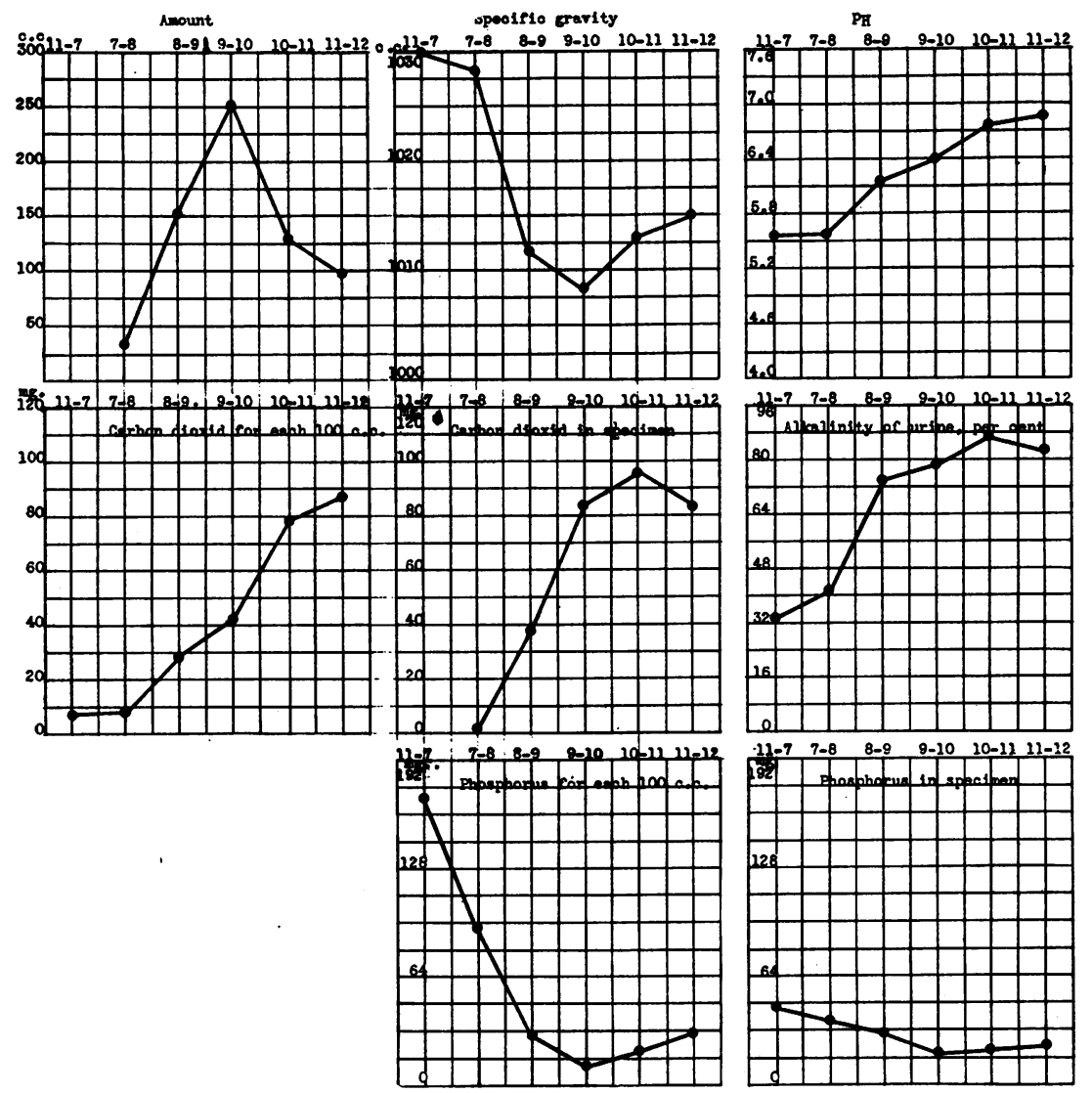

Fig. 1. Average Curves for Ten Normal Cases

The average curves of the various factors determined in normal cases are shown graphically in figure 1.

RESULTS IN ABNORMAL CASES (TABLES 1, 3 AND 4)

Similar types of cases are grouped together and those in which the complete study was made are indicated. From a study of these 
tables it will be observed that, while in some cases the test shows that all the factors are within normal limits, in others there are marked deviations from the normal. Leathes divided the cases which reacted abnormally into three groups: (1) those with little or no diuresis, but a normal alkaline tide; (2) those with diuresis, but no alkaline tide, and (3) those with neither a diuresis nor an alkaline tide.

The alkalinity per cent findings which are corroborated by the $\mathrm{pH}$ figures show that most of the cases in this series belong in one or another of these groups, although there are very few in group 1. To these three groups of cases, however, I would add a fourth small group, in which there was a definite acid tide during the morning, a reversal of the normal alkaline tide. This group will be discussed later at greater length.

It is to be noted that, even though the urine may react fairly normally with regard to diuresis, alkaline tide, or both, the range of the specific gravity may still be very limited.

The carbon dioxid in all cases, as was to be expected, varied inversely as the acidity.

In cases without an alkaline tide, there is a tendency, which may be very marked, to a fixation of the amount of phosphate excreted each hour. A study of the tables showing the phosphate estimation in the night specimens of normal and abnormal cases brings out an interesting fact. Under the conditions of this test the maximalnight concentration of phosphates in abnormal cases, estimated as milligrams of phosphorus for each $100 \mathrm{cc}$., is less than the minimal normal night concentration. The average figure for the abnormal cases likewise was much below the normal average. The maximal figure of total phosphates for the abnormal cases was the same as for the normals, but this was very exceptional, as the next highest figure, $244.9 \mathrm{mg}$., is almost the same as the minimal figure for the normals. On the whole, in abnormal cases, the phosphates, both total and relative, in the night specimen were definitely below normal.

\section{DISCUSSION}

In studying renal function from a new viewpoint, it is, of course, necessary that the results obtained be correlated with previously accepted standards. In this study seventy-four hospital cases were 
investigated, the majority of which were suffering from definite renal disease, although a few other conditions were included. In tables 5 and 6 the main clinical and functional findings are correlated together with the results of the present studies with regard to the morning alkaline tide.

The tendency toward a lack of diuretic response is evident, although in some cases the response is well within normall limits. In comparison with the minimal normal excretion of water, $260 \mathrm{cc}$., it will be noticed that in a large number of cases this function is limited, sometimes very markedly. The marked tendency toward fixation of the specific gravity in the urine of many of the cases is very striking, especially in table 1.

A study of the alkalinity per cent figures in tables 1 and 3 will show in what a large proportion of cases of chronic glomerulonephritis there is an abolition, either partial or absolute, of the alkaline tide. To be well under the standard set by normal cases, I have considered that all with a difference between the initial and maximal alkalinity per cent of less than 15 should be considered in this class. In figure $2 \mathrm{a}$ number of curves of the cases of this group are shown with the normal curve superimposed. The flattening of the curves is at once apparent.

Very few cases other than those of chronic glomerulonephritis and subacute diffuse nephritis fall below this standard, the exceptions including two cases of malignant hypertension, two of arteriosclerosis, two of focal nephritis, one of gout, one of bilateral polycystic kidneys, and one of bilateral hydronephrosis. This last case, in which there was an acid tide, is discussed with that group.

Figure 3 represents the curves found in a case of chronic glomerulonephritis which was clinically severe (case 49); the patient has since died. In each section of this figure the normal average curve is also given for comparison. As will be observed, the hourly output of urine is almost constant, the specific gravity is virtually fixed, and the alkalinity per cent shows very little change. The $\mathrm{pH}$ figure is the same for each specimen and is at a high acid level for urine. All these indicate a fixed acid urine. The carbon dioxid, in accordance with the $\mathrm{pH}$, remains very low and fixed, and the phosphates also show a marked tendency toward fixation.

Thus it would appear that in such cases of chronic and subacute 
glomerulonephritis the kidneys excrete a more or less fixed urine with the amounts of the main elements little changed from hour to hour. These facts indicate that the kidneys in such cases constantly excrete their maximal amount, and have lost that reserve excretory function so characteristic of normal kidneys. The kidneys in this case (case 49) were unable, even at the height of their function, to eliminate the normal waste products, which therefore accumulated in the blood, as

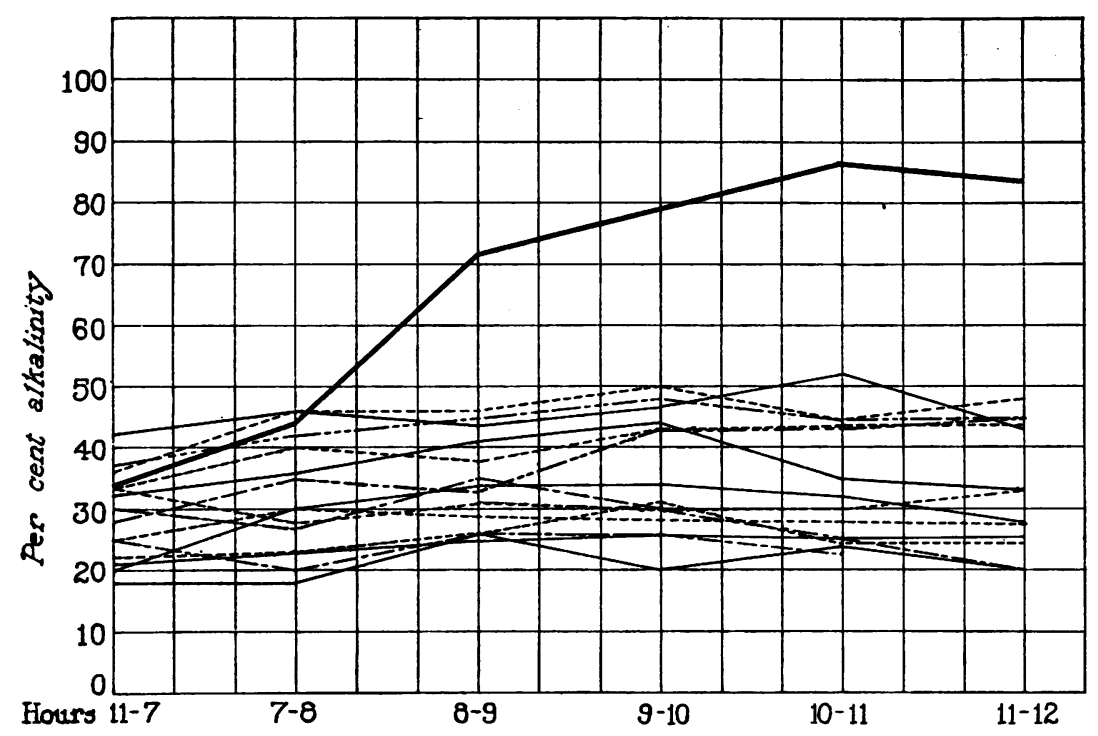

Fig. 2. Curves in Cases Without Alkaline Tme Contrasted with Curve in Case with Alkaline Tide

Composite normal. Other curves, cases without alkaline tide

indicated by a blood urea of $345 \mathrm{mg}$. for each $100 \mathrm{cc}$., and a blood creatinin of over $12 \mathrm{mg}$. for each $100 \mathrm{cc}$.

By studying the clinical findings given in tables 5 and 6 , and by observing the number of patients in groups 1 and 3 who have died, an indication of the severity of some of the cases will be obtained. Included in these groups, of course, are other patients in whom the nephritis was clinically comparatively mild. Although the urinary findings obtained in different cases by this test vary considerably, as would be expected, in general it may be said that only in cases of 
clinically severe nephritis is there an abolition of the alkaline tide. These cases also show that there may be marked fixation of the specific gravity in spite of an alkaline tide, a diuresis well within normal limits, or both. As indicated in the results with abnormal cases,

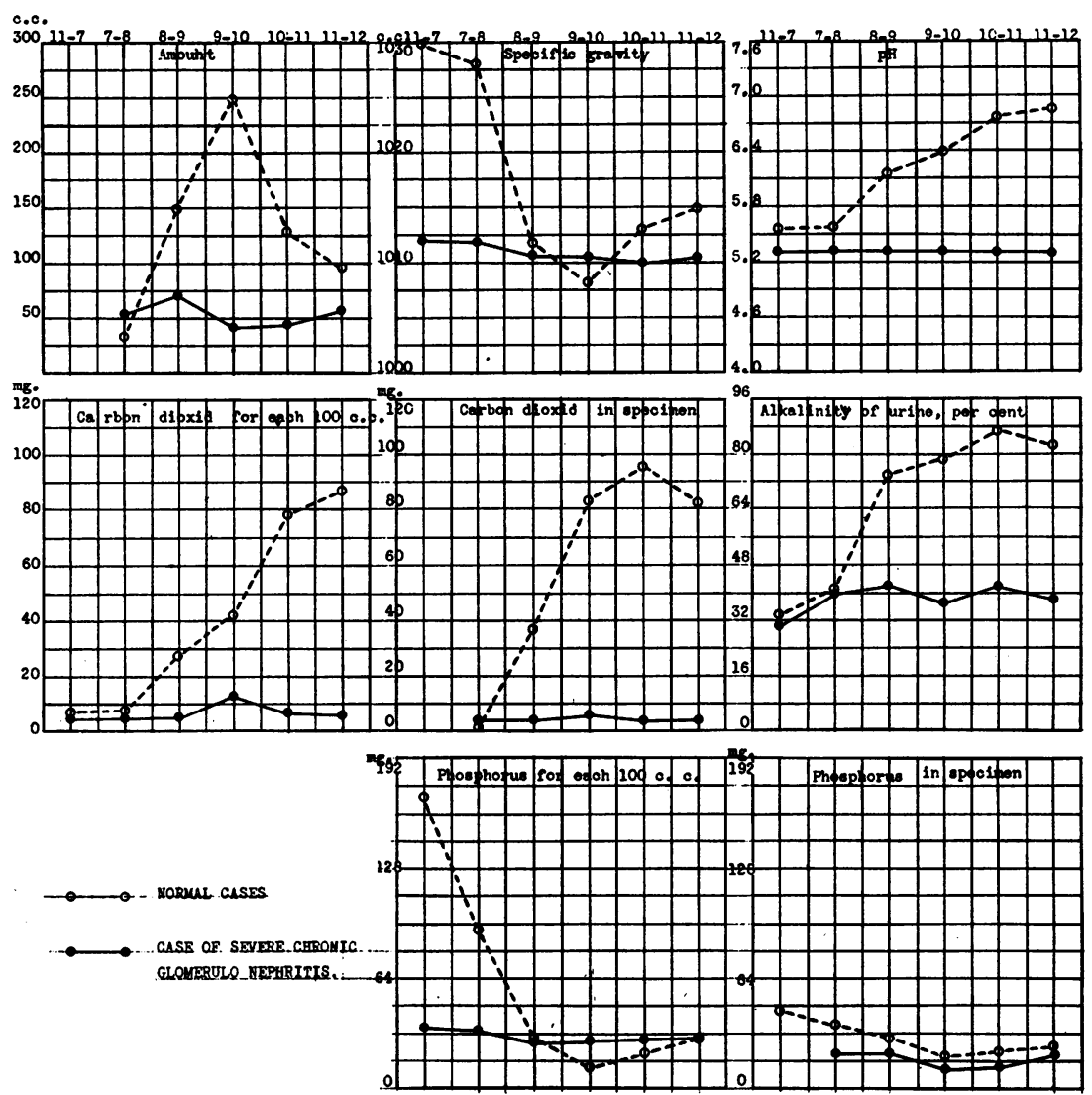

Fig. 3. Curves in Case of Severe Chronic Glomerulonephritis Contrasted with Curves in Average Normal Case

O- - - - O Normal cases.

- Case of severe chronic glomerulonephritis

some of the patients who were tested (besides those already mentioned) showed limitation of function in some respects, but these findings were not constant or marked enough to require particular comment.

Since the carbon dioxid in the urine depends on the acidity, it would 
seem that the estimation of the carbon dioxid had no practical value. The tendency of the phosphates to be fixed in the cases with no alkaline tide is significant, but the lowering of the phosphate content of the night urine in cases with renal involvement would appear to be even more so. I have never seen any record of such a lowering of the phosphate content in the night urine of nephritic patients, and such an estimation may prove of practical value. However, further investigation along this line must be carried out. Variations may depend on the diet and on the partition of the phosphate excretion between urine and feces. All the abnormal patients in which this was found were on a limited, controlled diet, while the normal subjects were not restricted.

Table 7 gives the results of the estimation of the carbon dioxid combining power of the blood plasma in a number of normal and abnormal cases. In none of the abnormal cases studied in regard to this point were there symptoms suggesting acidosis. As was to be expected, the alkali reserve of the blood of normal subjects showed no significant change during diuresis. In the group of clinical cases of nephritis studied, there was no diminution of the reserve alkalinity of the blood, and, as in the normal cases, there was no significant change during diuresis.

An acid tide was encountered in four cases, and in these there was a definite increase in the acidity during the morning. The first case in which this phenomenon was encountered was case 10. The result was thought at first to be incorrect, but the test was repeated three times without variation in the result. It is true that in this case the specimens were not examined as soon as they were passed, but, as this acid tide was an isolated phenomenon among the large group of cases and as it occurred so persistently, its presence may be considered as established. This case was one of chronic glomerulonephritis. The clinical findings were: blood pressure 150 systolic and 90 diastolic; albumin 2; no casts or red blood cells; blood urea $289 \mathrm{mg}$. for each 100 cc.; blood creatinin $6.2 \mathrm{mg}$. for each $100 \mathrm{cc}$.; no edema, normal eye-grounds and a phenolsulphonephthalein return of 5 per cent. The patient died later.

This acid tide was next observed in case 70. The diagnosis, bilateral hydronephrosis, was confirmed at necropsy. The albumin varied 
from 1 to 3 while the patient was in the hospital; the maximal blood urea was $327 \mathrm{mg}$. for each $100 \mathrm{cc}$; t the maximal blood creatinin was $22.6 \mathrm{mg}$. for each $100 \mathrm{cc}$.; edema was present; the eye-grounds showed a pallor of the discs but were otherwise negative; there was no return of phenolsulphonephthalein, and the blood pressure was 158 systolic and 94 diastolic. The $\mathrm{pH}$ in this and the remaining two cases confirmed the presence of an acid tide.

The third patient (case 40), was a young man, aged twenty-three, with a diagnosis of chronic glomerulonephritis. His urine contained albumin varying from 1 to 3 , and microscopically showed a few casts, and a considerable number of red blood cells. The blood urea was 74 $\mathrm{mg}$. for each $100 \mathrm{cc}$, and the blood creatinin $1.8 \mathrm{mg}$. for each $100 \mathrm{cc}$; edema was present; the eye-grounds were normal; the phenolsulphonephthalein return was 40 per cent, and the blood pressure 194 systolic and 122 diastolic. This patient felt well enough to be up and about. His death occurred shortly after leaving the hospital.

In the fourth case (case 46) the disease diagnosed chronic glomerulonephritis. His blood pressure was 200 systolic and 140 diastolic; his urine showed albumin 1 to 2, a few casts and red blood cells. His blood urea was $154 \mathrm{mg}$. for each $100 \mathrm{cc}$., and his blood creatinin 2.7 $\mathrm{mg}$. for each $100 \mathrm{cc}$. There was slight edema. The retinal arteries showed a reduction of caliber, and there was a suggestion of edema of the discs with a small, diffuse hemorrhage above the left one. The phenolsulphonephthalein return was 5 per cent. This patient had a long and severe illness while here, his condition being considered very critical. The patient lived a short time on a reduced diet, and with limited activities. Following indiscretions he rapidly became worse, and died fourteen months after this test was made.

In this case each specimen was examined at once, and every precaution taken to avoid any change in hydrogen-ion concentration.

A summary of the findings in these four cases will be found in table 8 and figure 4 , which gives the curves of the alkalinity per cent figures, the normal curve being superimposed for comparison. They show graphically how little variation there is in the hourly output of urine, the virtually fixed specific gravity, and the unmistakable acid tide. The crossing that occurs between the normal curve and those of the acid tide cases is also striking. The abnormal urine shows first a 
relatively high alkalinity but becomes progressively less alkaline until noon, while in normal urine, the reverse is true.

So far I have been unable to find any record of an actual demonstration of an acid tide in the urine. This occurred only in severe cases, and in three of the four cases bacterial infection of the lower urinary tract could be excluded. No alkaline treatment was being employed. I believe, therefore, that such an acid tide occurs only in the end stages of some cases with marked involvement of the renal parenchyma. Thus it would seem, no matter what the apparent

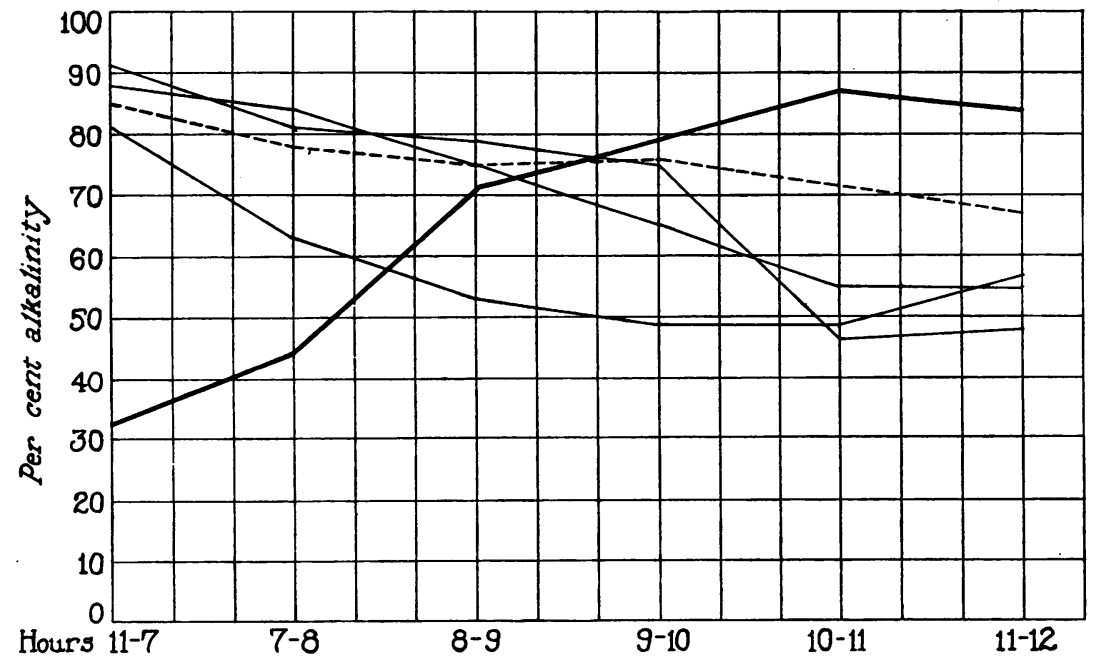

Fig. 4. Curves in Acm Tme Cases Compared with Curve in Normal Case Composite normal. Other curves, cases with acid tide

general condition of the patient at the time of the test, that the presence of an acid tide is of grave prognostic import.

It is suggested that a test similar to Leathes' test might with advantage be used instead of the water test of Volhard and Fahr, for the former shows not only the ability of the kidney to excrete water, and the range of specific gravity, but also the presence or absence of the normal alkaline tide. Any objection to a titration test could be overcome by substituting for the estimation of the alkalinity per cent the determination of the $\mathrm{pH}$ as done by Henderson and Palmer. Moreover, patients find it much easier to take the comparatively small 


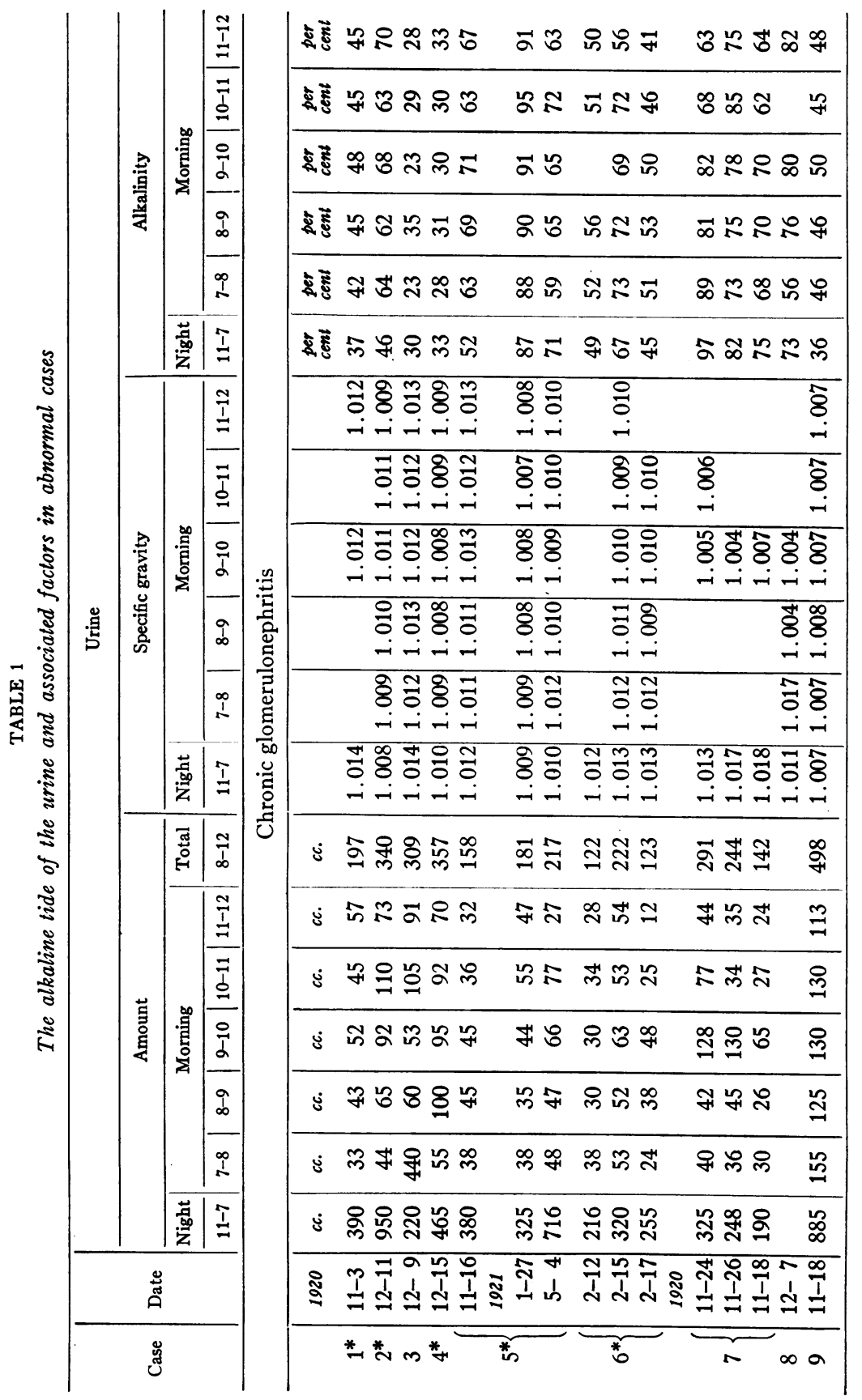




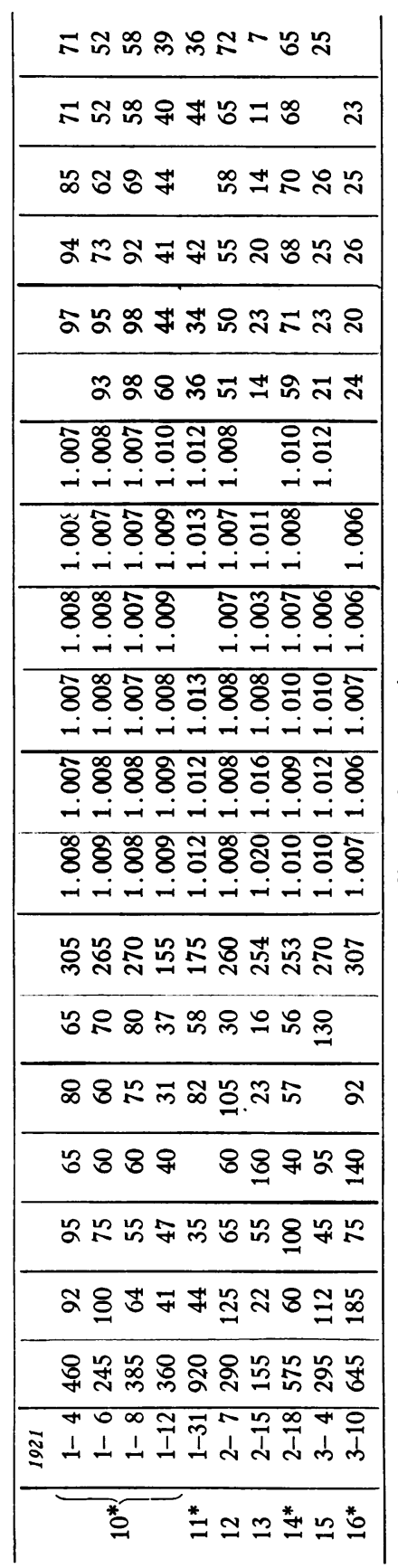

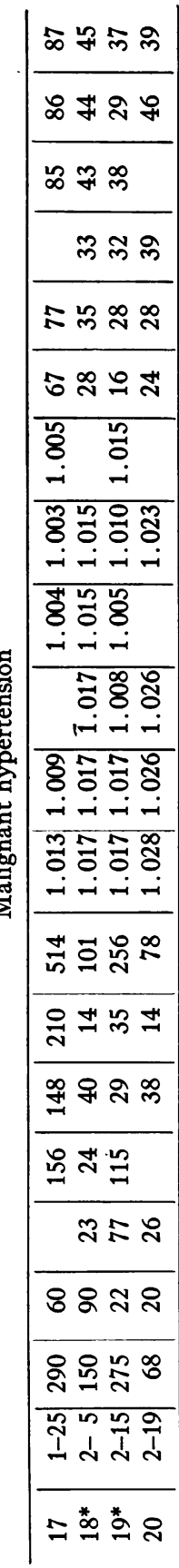

\begin{tabular}{|c|}
\hline mミล \\
\hline ஜ \\
\hline ఫ্ $\infty$ \\
\hline హ゙ そ \\
\hline 闬 \\
\hline กี : \\
\hline 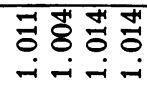 \\
\hline 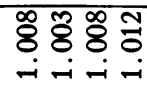 \\
\hline రิ \\
\hline 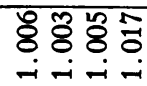 \\
\hline 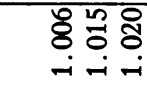 \\
\hline 웅 \\
\hline 茫 \\
\hline 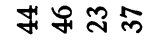 \\
\hline ㄴํㅇ용ำ \\
\hline 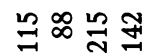 \\
\hline 요읏 \\
\hline$\stackrel{2}{a}$ 워 \\
\hline 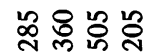 \\
\hline 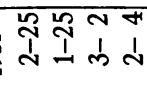 \\
\hline$\widetilde{N} \approx \mathbb{N}$ \\
\hline
\end{tabular}

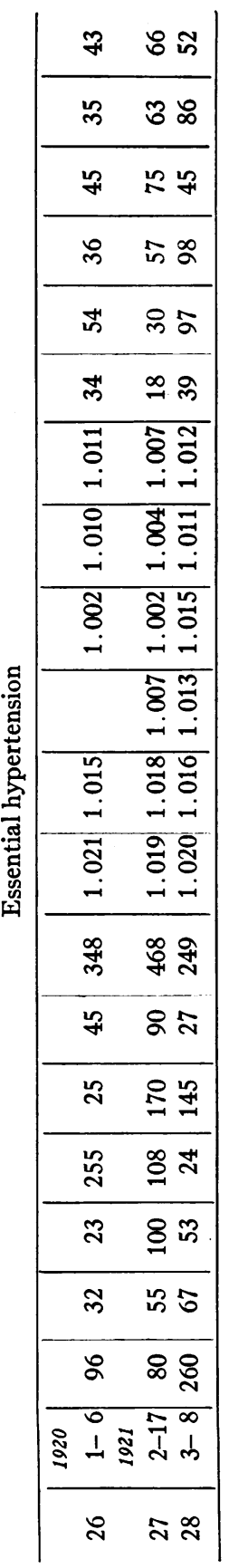


MORNING ALKALINE TIDE OF URINE

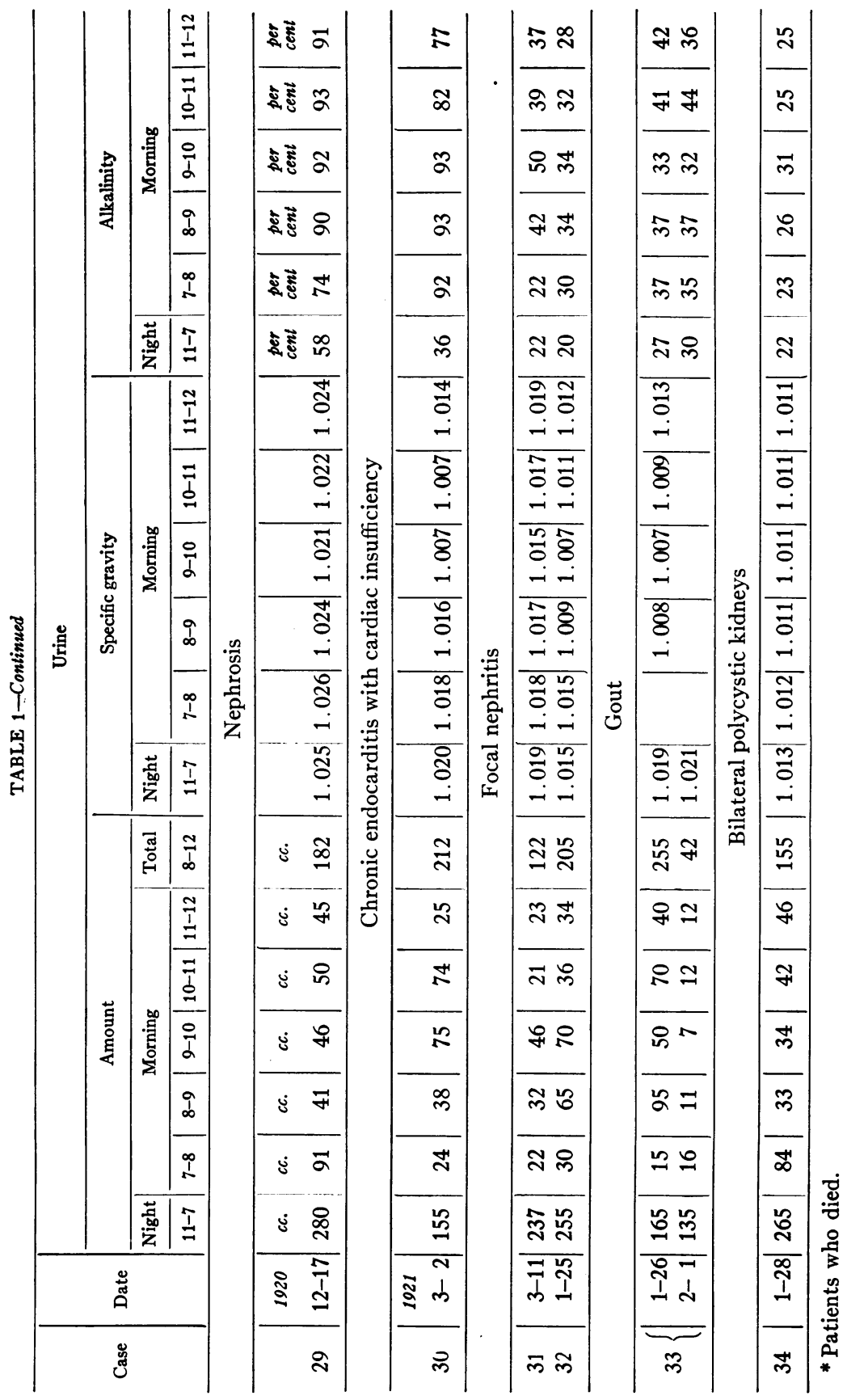




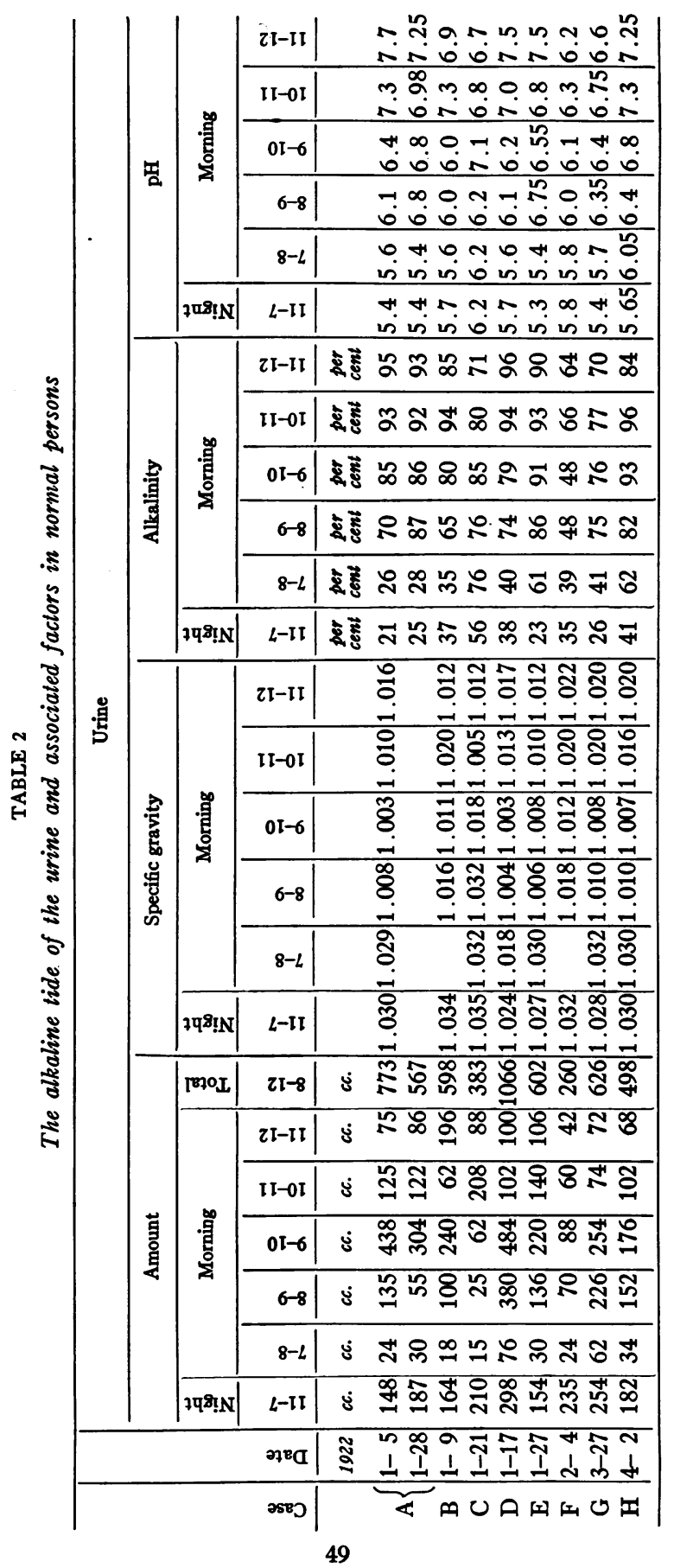




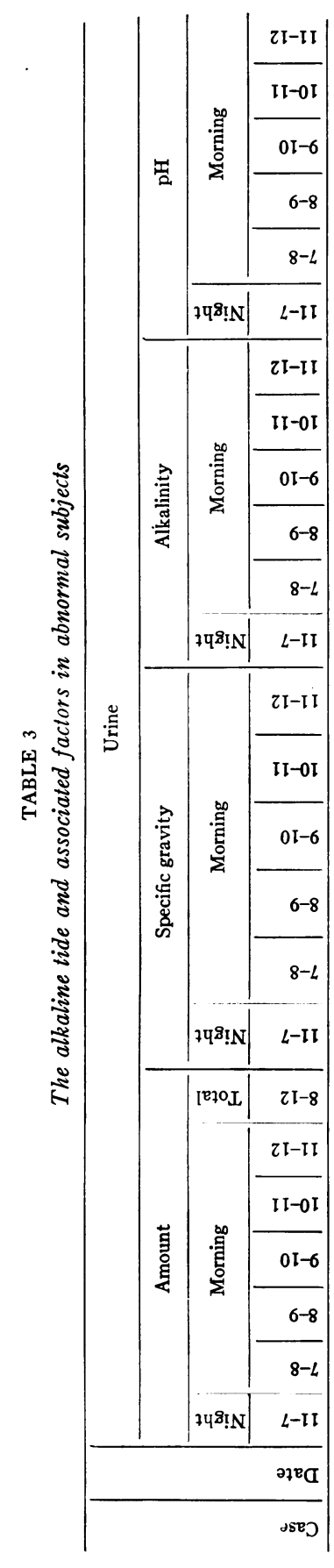

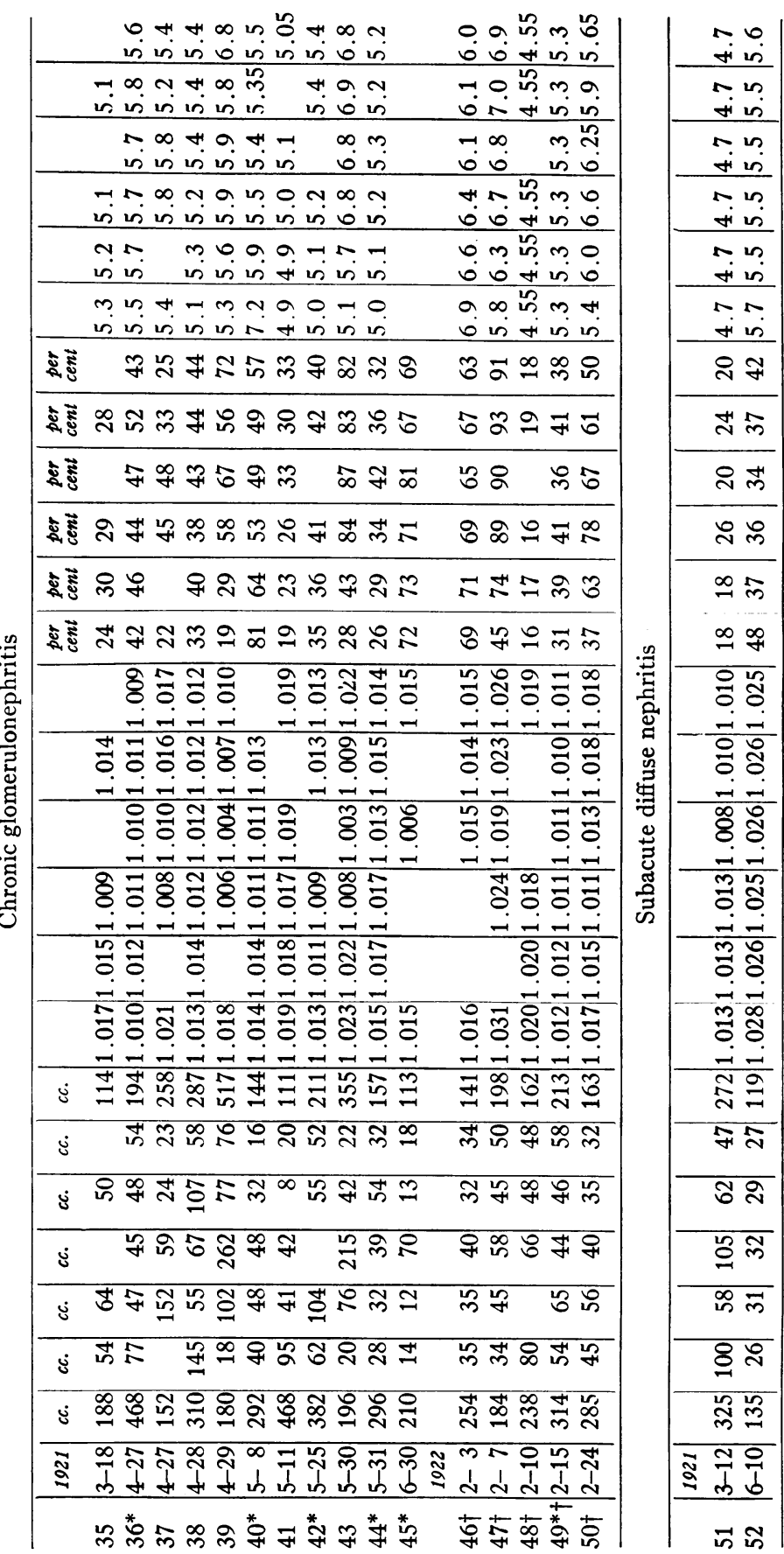



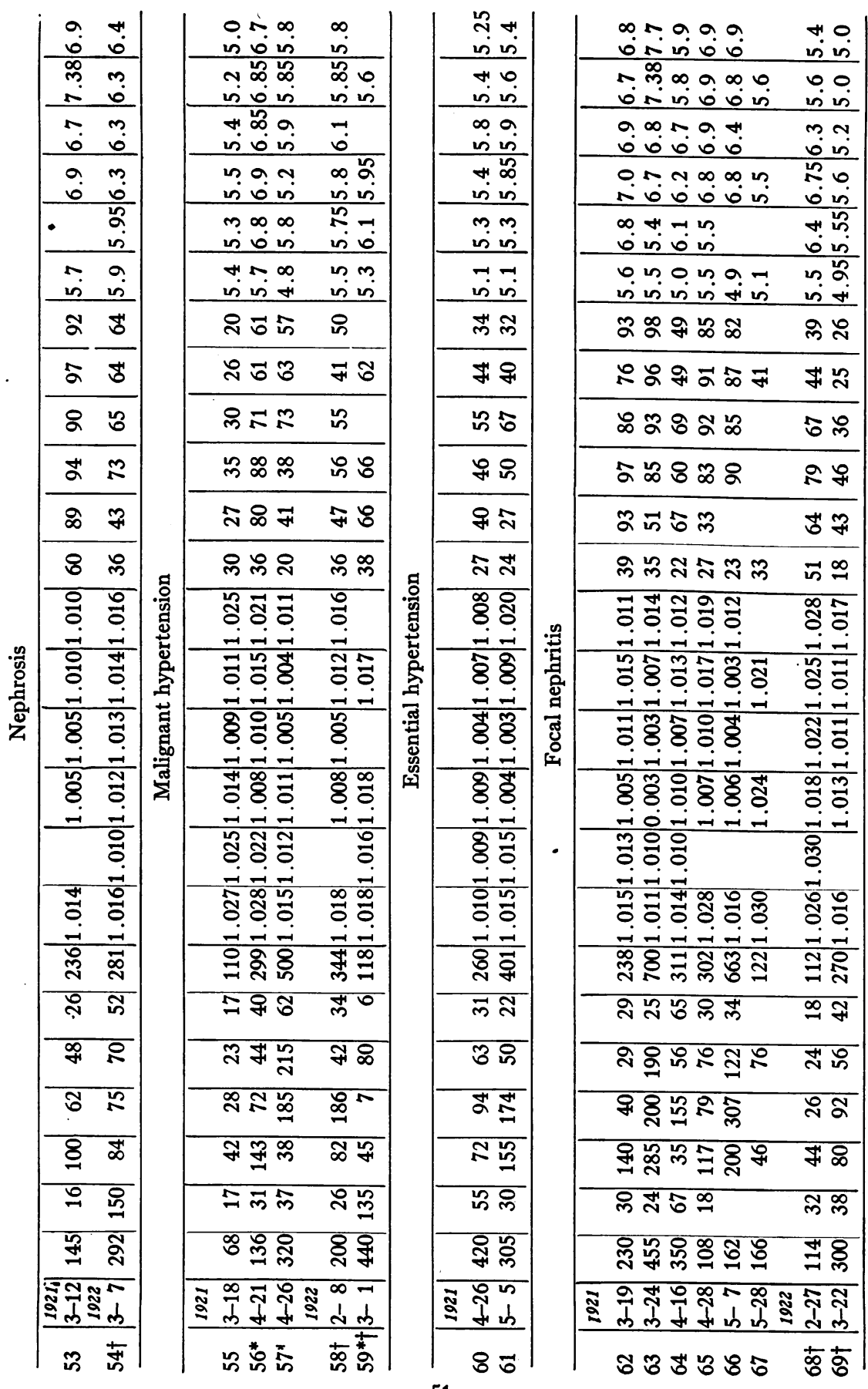


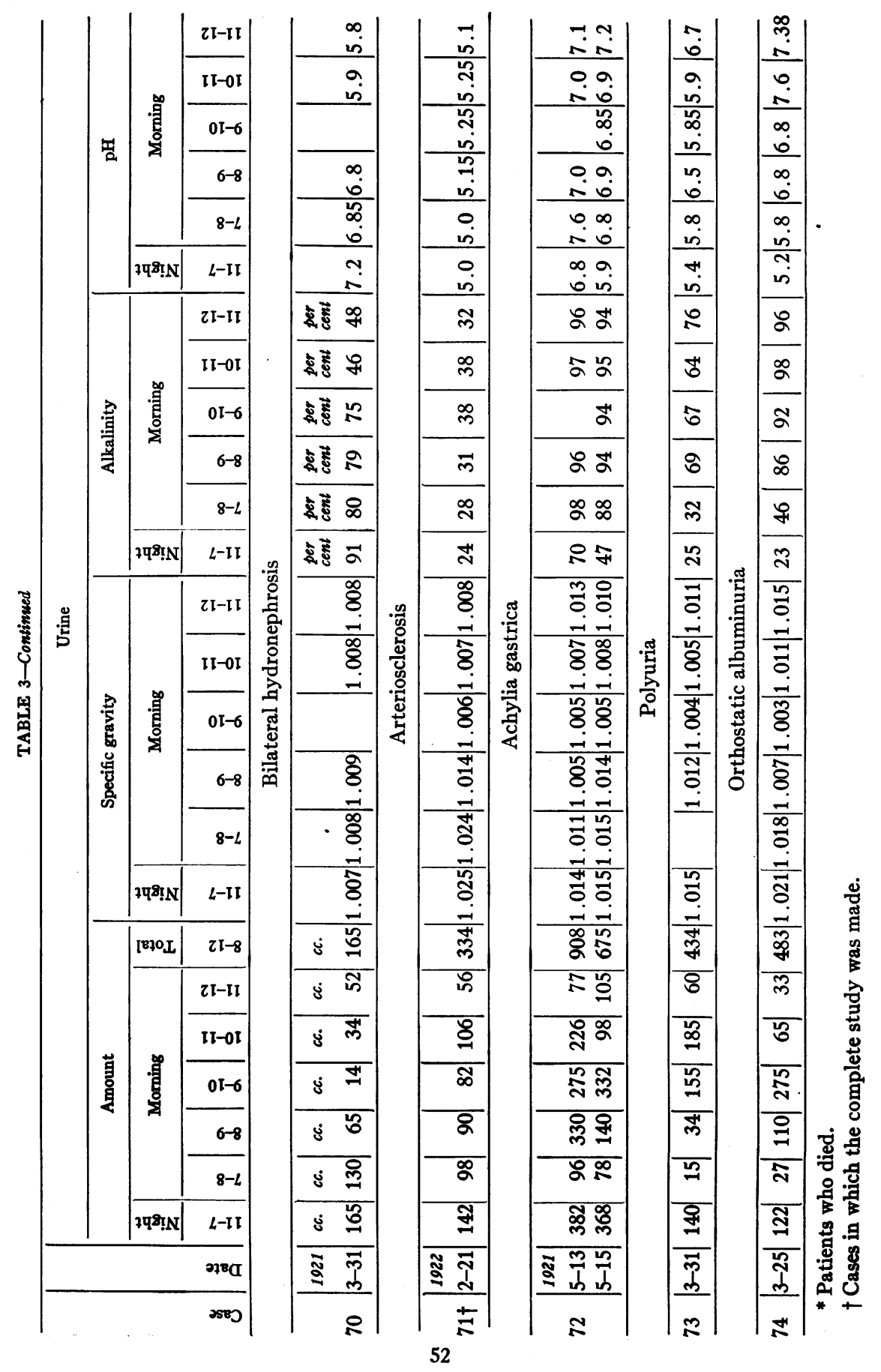


amount of water required in this test. The estimation of the carbon dioxid in the specimens would not seem to be of practical value since it varies in amount directly as the hydrogen-ion concentration.

\section{CONCLUSIONS}

1. In this paper are reported the results of investigation of the night specimens and hourly morning specimens of urine in a series of normal and abnormal subjects. At 8:00 a.m., $500 \mathrm{cc}$. of water was given on an empty stomach. Most of the abnormal cases were of renal lesions.

2. Normal subjects, as demonstrated by Leathes and confirmed by my experiments, always show a diuresis and an increase in alkalinity during the morning, while abnormal subjects may react like the normal, or show limitation, either partial or complete, of either or both.

3. In addition, among the abnormal subjects examined, there were a few with a high initial alkalinity and an acid tide during the morning.

4. The specific gravity may show little variation even with a diuresis within normal limits, an alkaline tide, or both.

5. Cases with no alkaline tide are usually severe clinically. An acid tide is of grave prognostic import.

6. The curve of the $\mathrm{pH}$ figures parallels that of the alkalinity per cent.

7. In the cases reported here, both normal and abnormal, a higher $\mathrm{pH}$ figure was always accompanied by increased relative carbon dioxid, and a more acid urine by a decrease in carbon dioxid.

8. The phosphates of normal subjects, as demonstrated by Fiske, have an initial drop followed by a late rise during the morning. In the present series the night specimen was found to have a much lower phosphate content in abnormal than in normal subjects.

9. The results of these investigations show that this test may be of clinical value from the point of view of diagnosis and prognosis. 

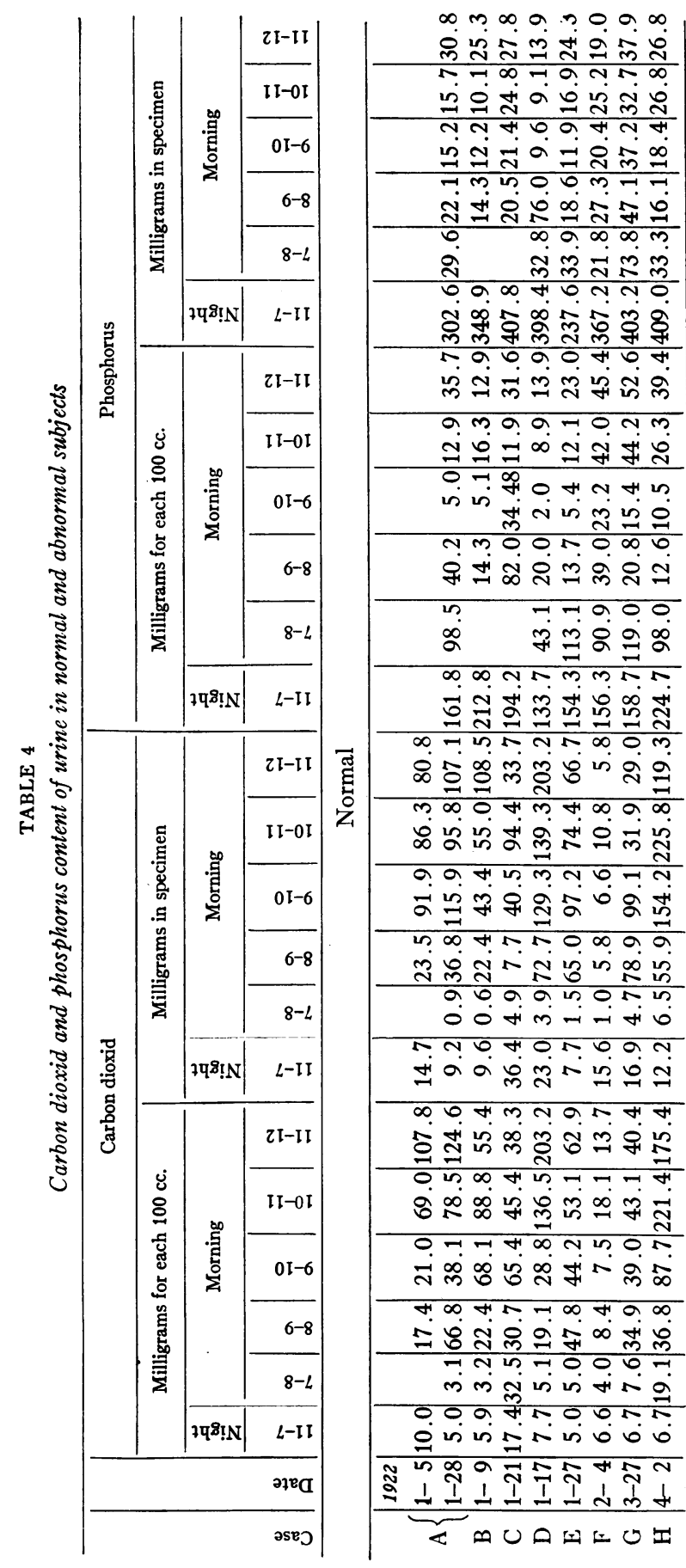

$\infty \infty$ N $\infty$ m పేత छี Zㄱ

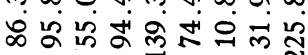
व. สं notra

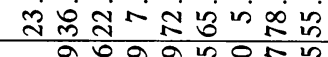
०0 $m$ in $N$ in a ฟ ఈำ అ $0.00 \ln 2$

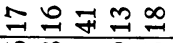
0क a in $\circ 0$ 음 ก. 워느 in m० स- n 응 용 in $0 \infty \infty 0$

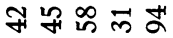
०. พ9.9 피요요 우두

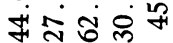
पू है

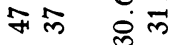
$\infty$ म लm กี O NO A 능 पन च म व $\infty$ V $+\dot{\infty}-\dot{\infty} 0$

두 $\infty \infty$ $\forall \dot{\infty} \dot{s}$ in m ? m ○ ल ○ $m$ N 0 ก กิ $N \infty$ o $\infty= \pm$ 읭 म 的

$\infty \infty \infty \infty 0$

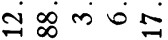
वठㅁㄷㅏ $\therefore$ 요 o $\infty$ in a. +1:0 a $\infty-1+i$ in बे कित्र लं $a+$ in mన

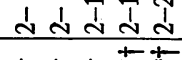
क क

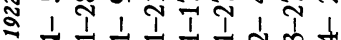
克声京高蓄 


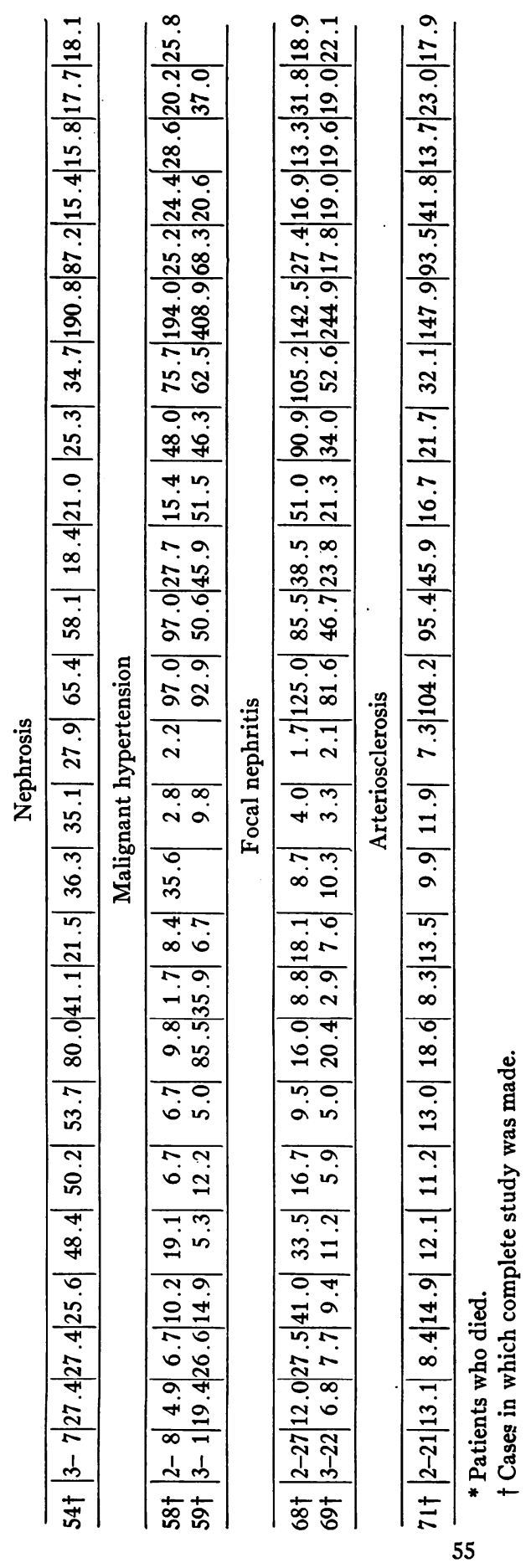




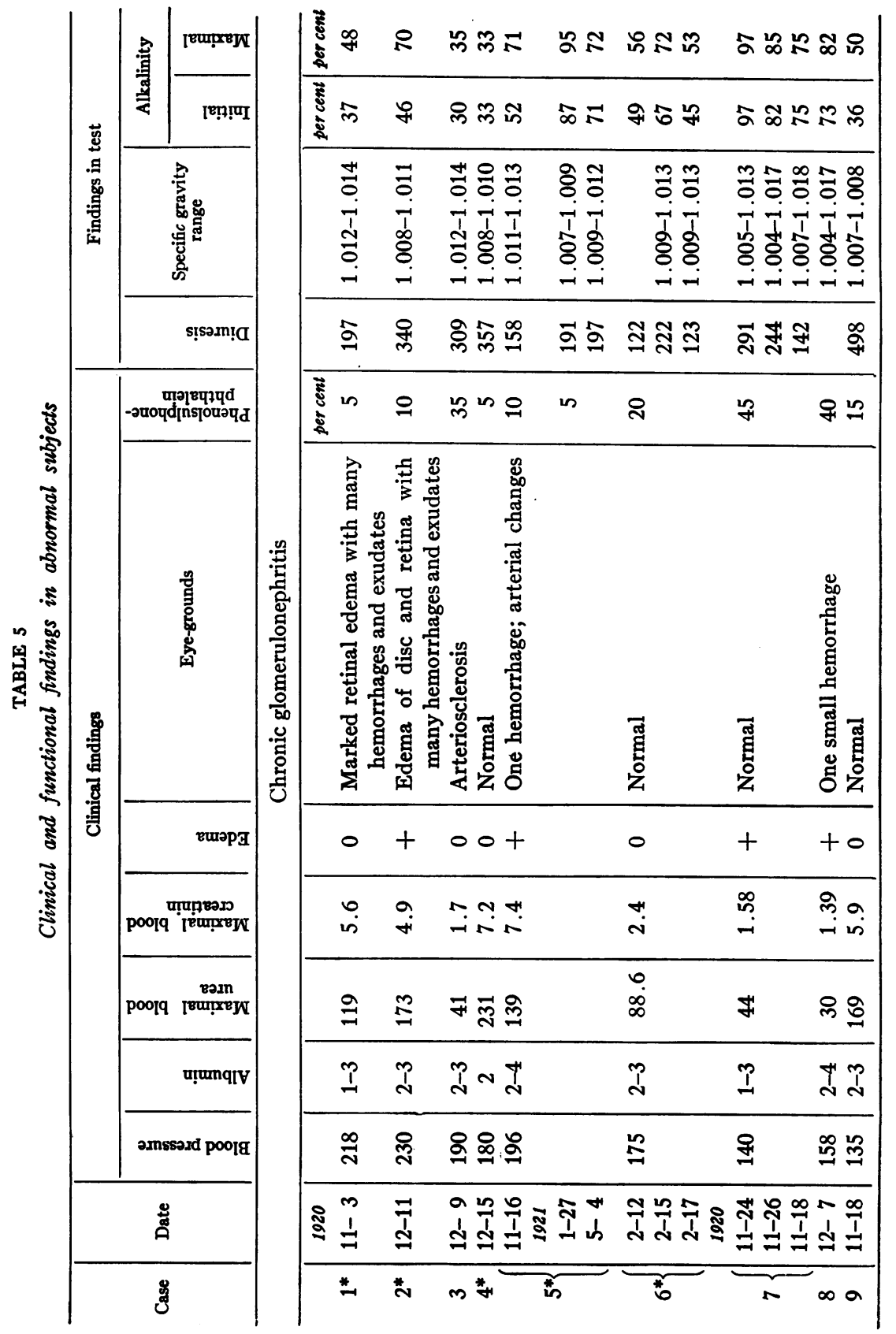




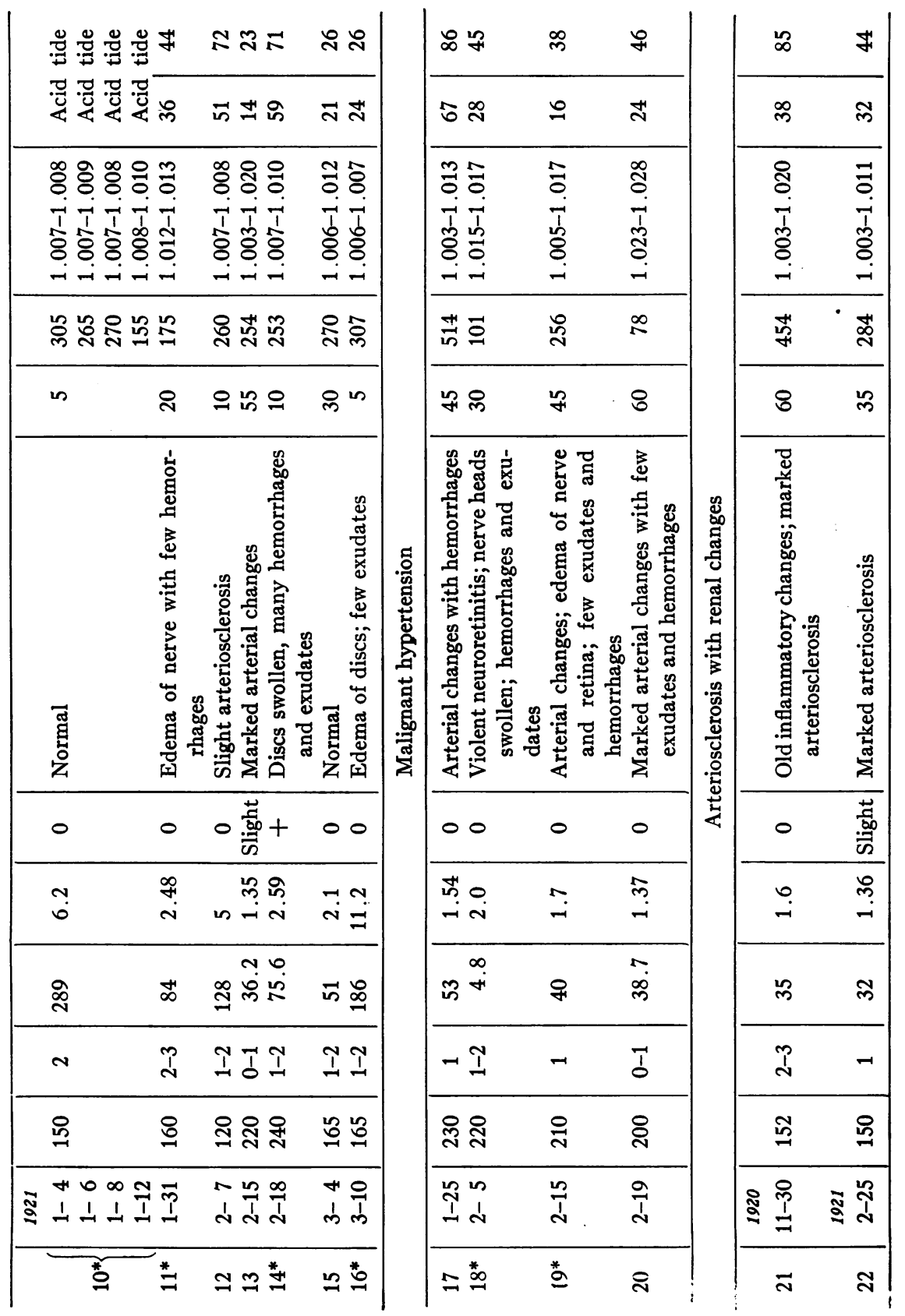




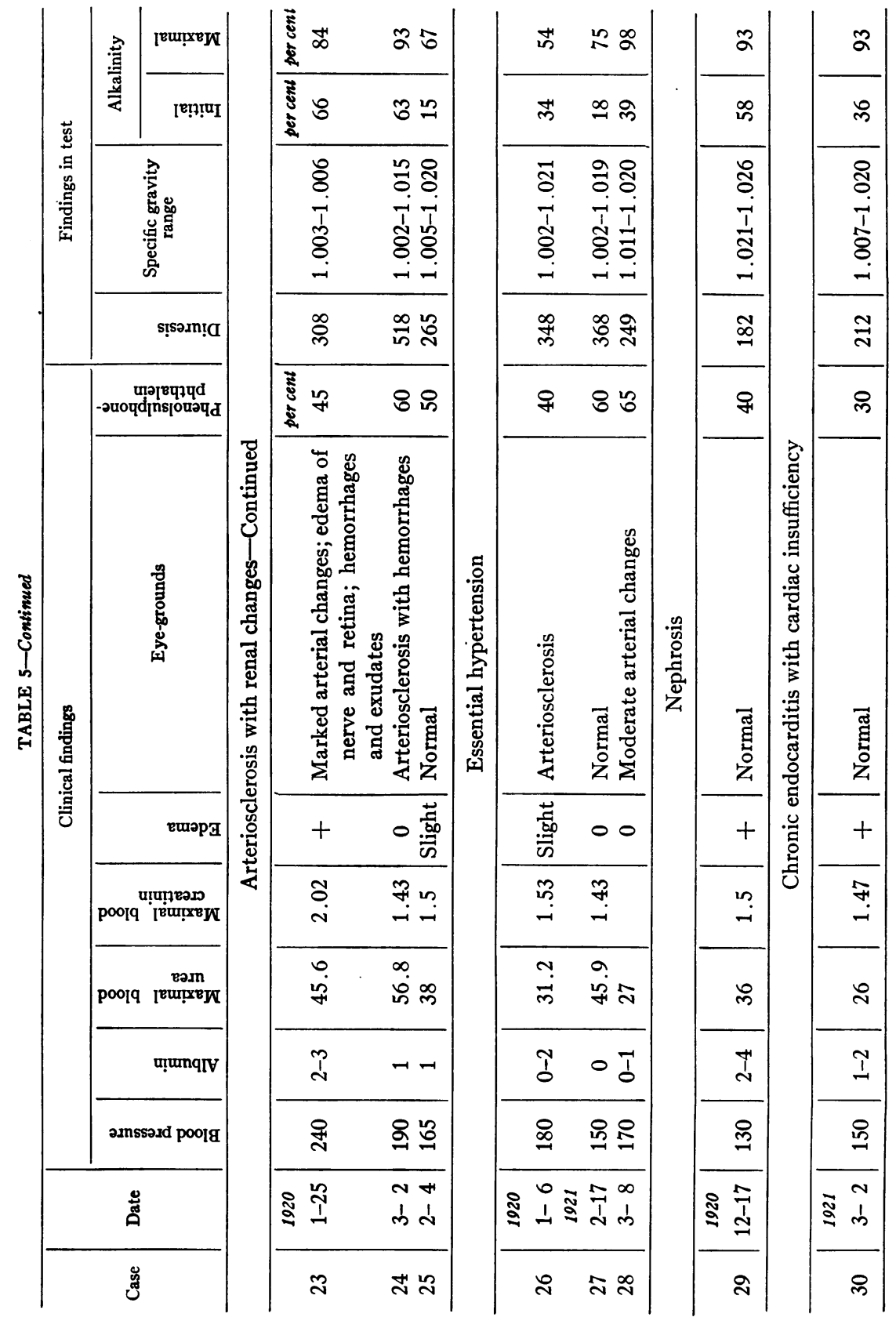




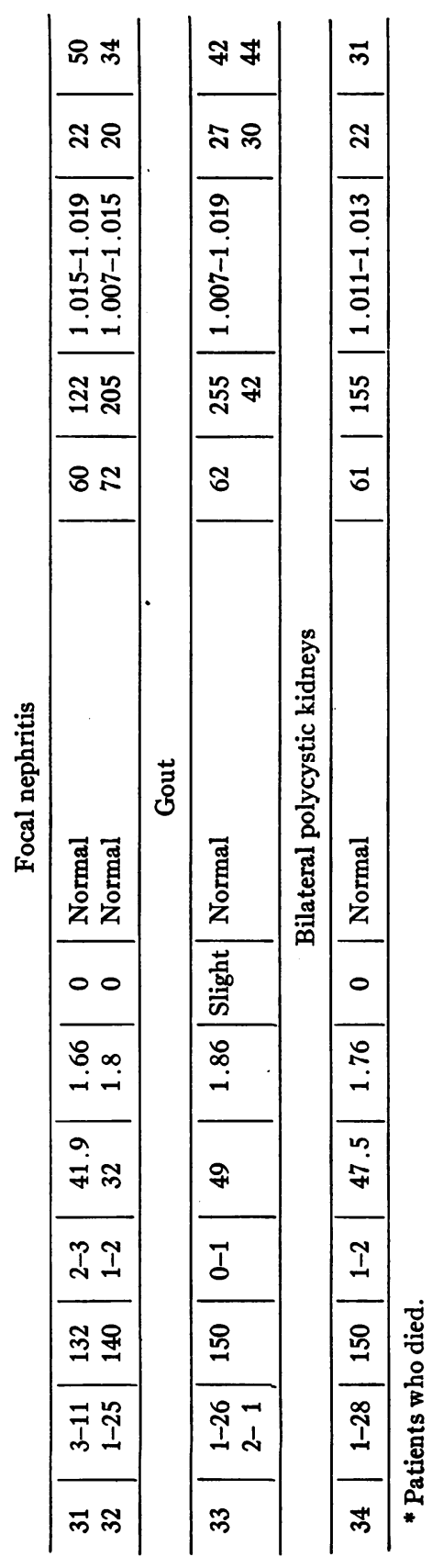




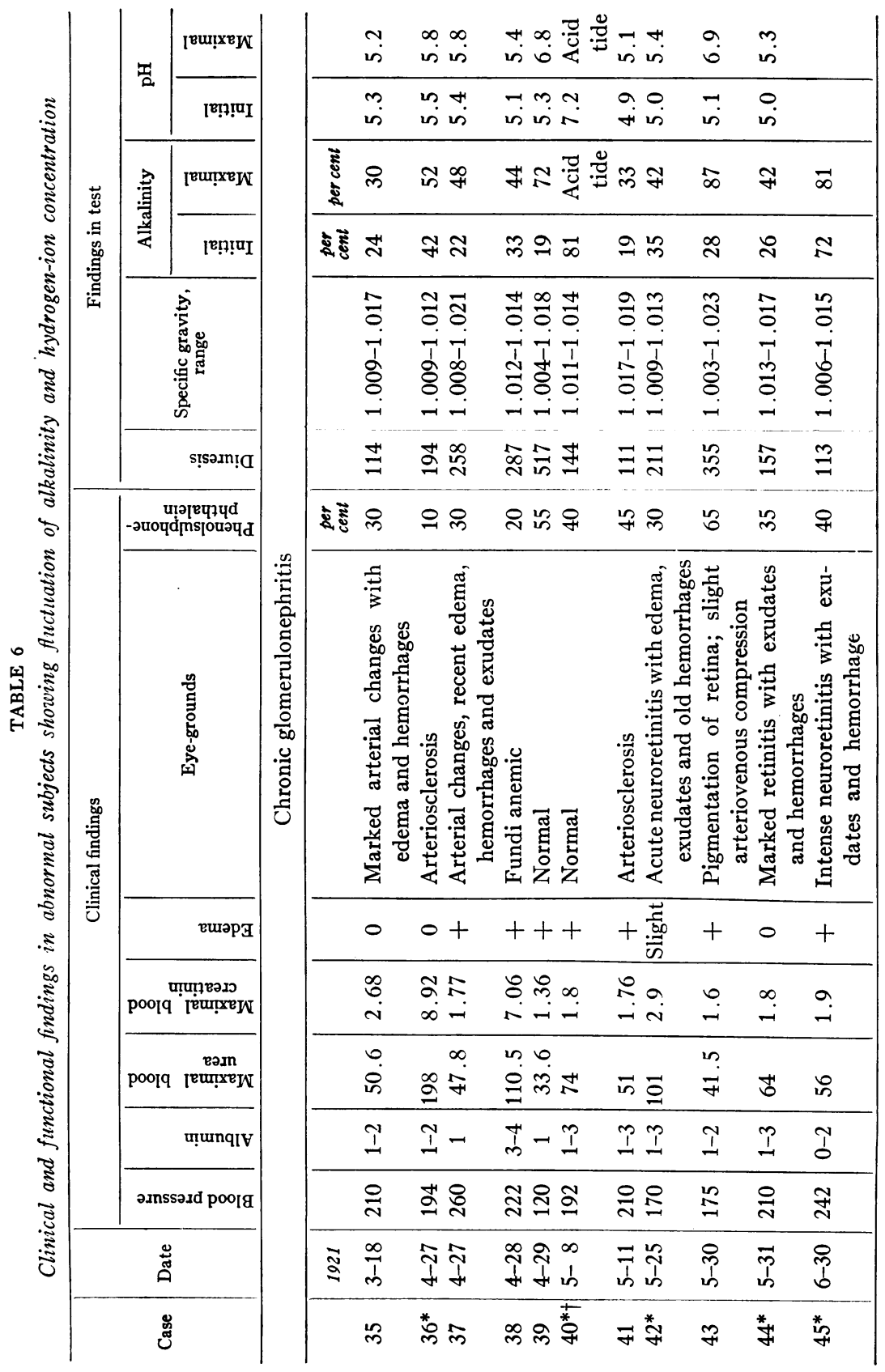


JOHN E. MCCORVIE

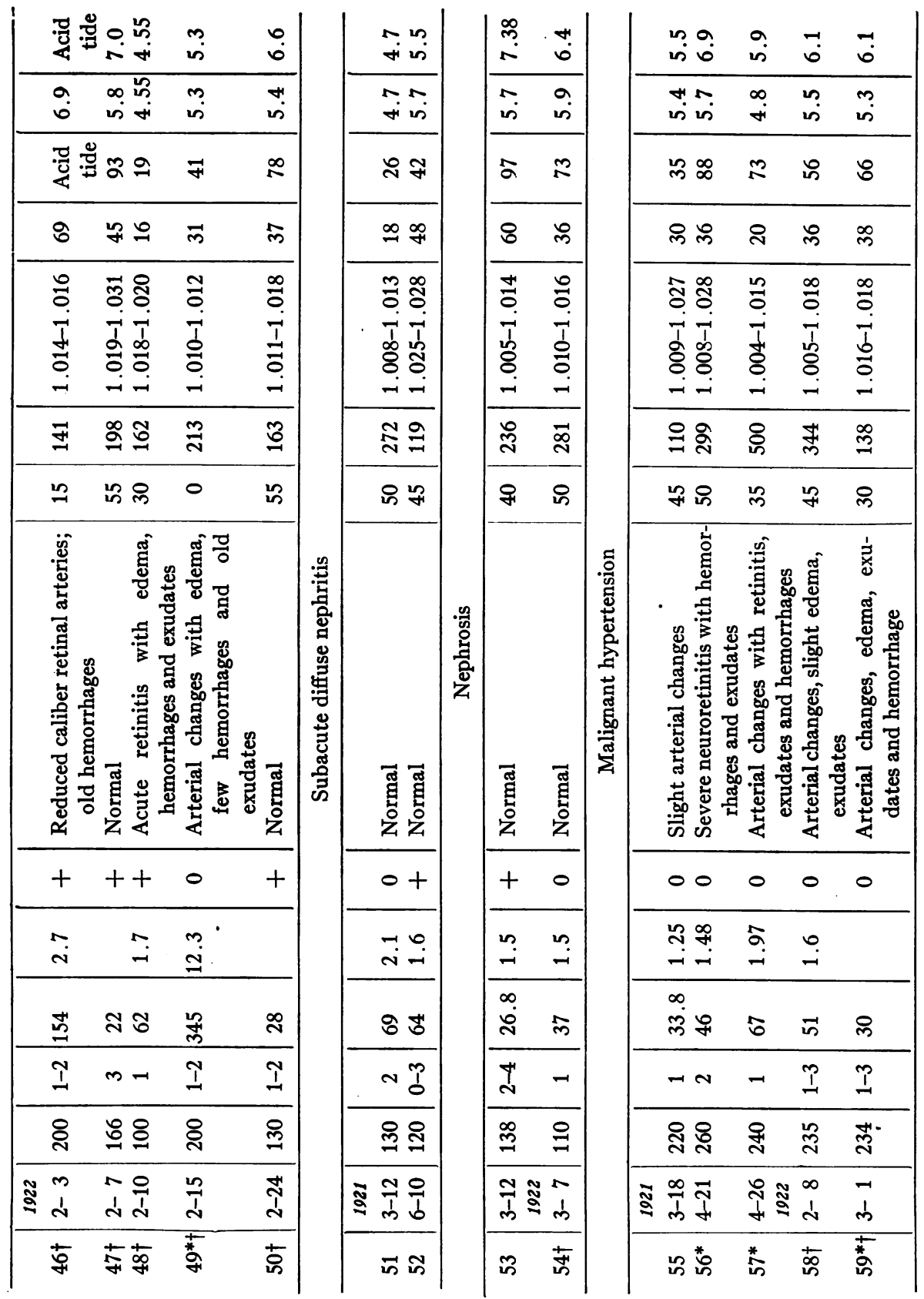




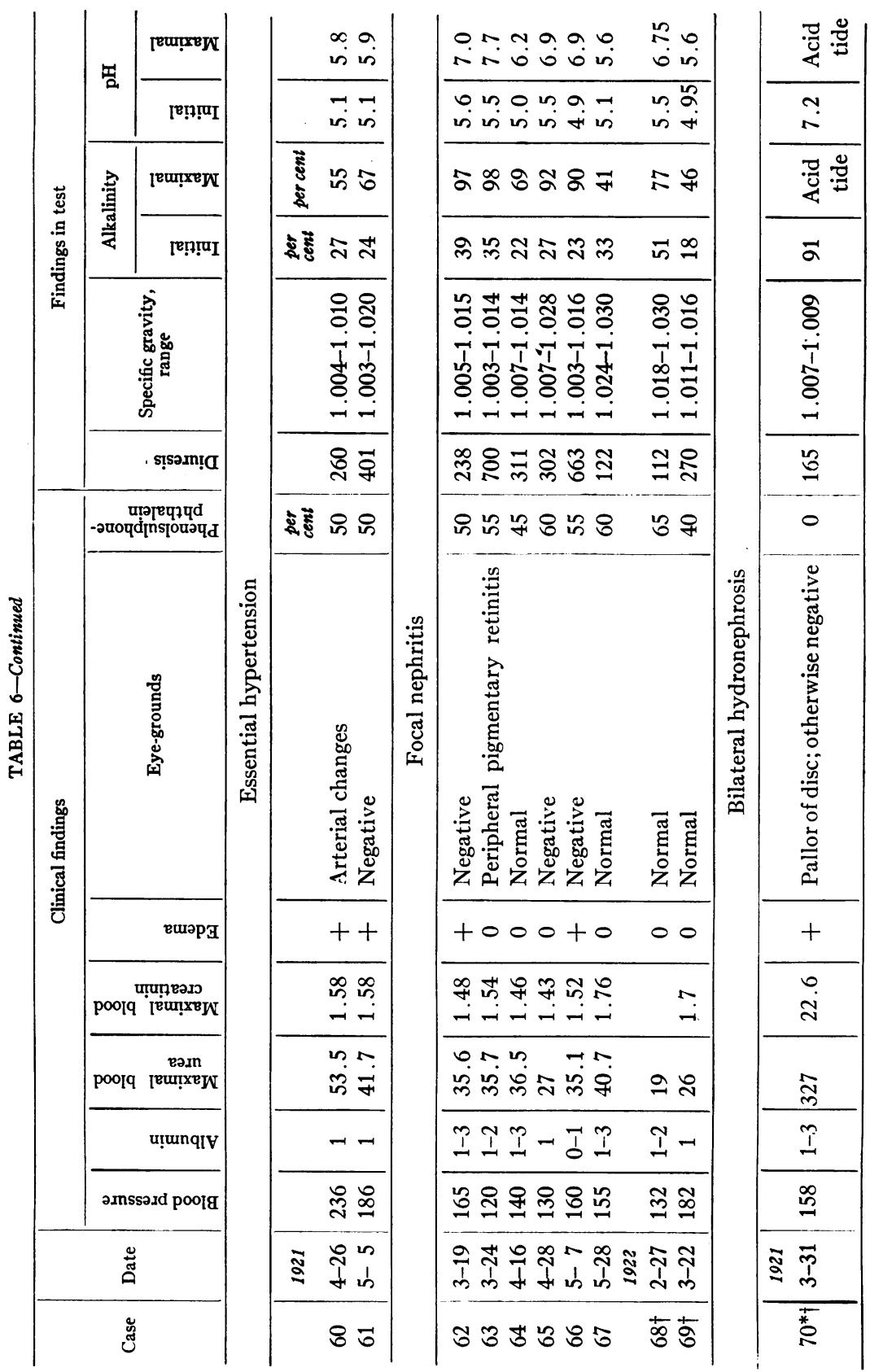


JOHN E. MCCORVIE

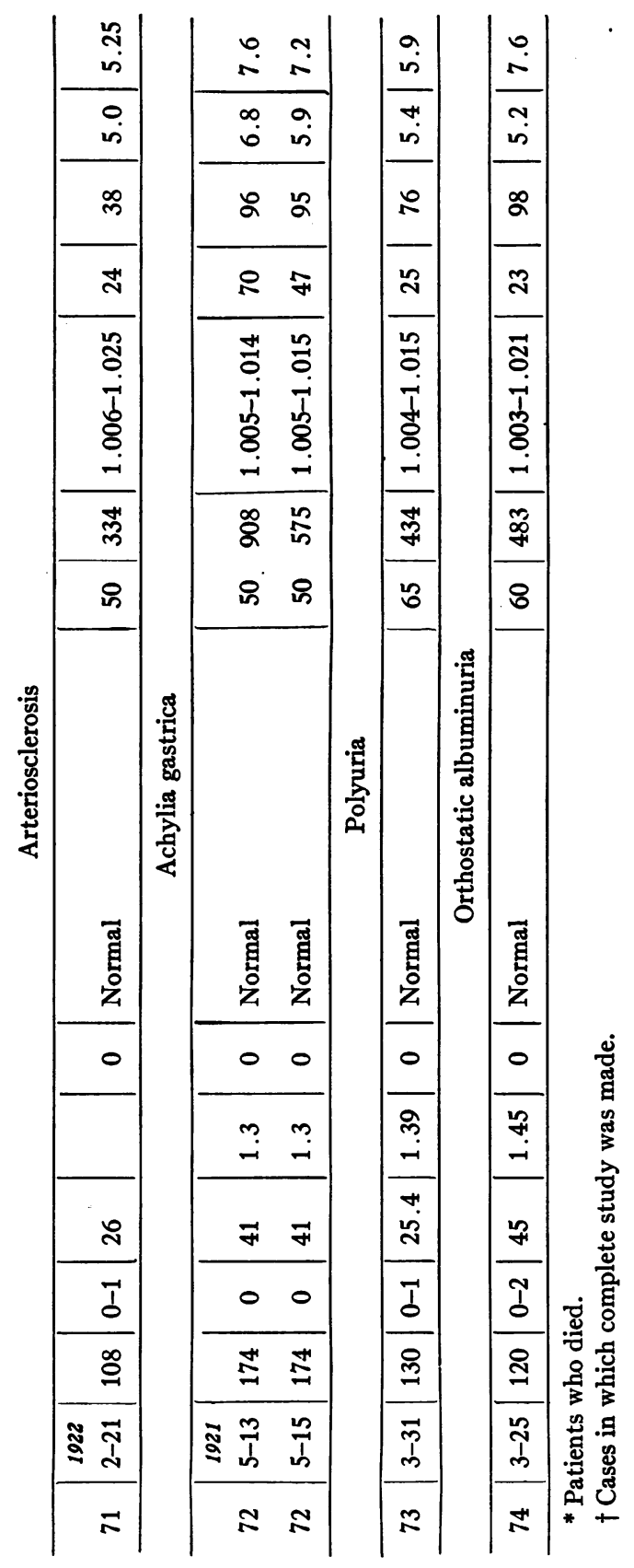


TABLE 7

Carbon dioxid combining power of blood plasma

\begin{tabular}{c|l|c|c}
\hline Case & \multicolumn{1}{|c|}{ Diagnosis } & Before diuresis & After diuresis \\
\cline { 2 - 3 } & Normal & 58.9 & 56.0 \\
A & Normal & 59.8 & 55.1 \\
B & Normal & 62.6 & 59.8 \\
C & Normal & 60.7 & 60.7 \\
D & Normal & 67.3 & 67.3 \\
E & Normal & 67.3 & 67.3 \\
F & Normal & 59.6 & 59.6 \\
G & Chronic glomerulonephritis & 71.5 & 70.6 \\
46 & Chronic glomerulonephritis & 55.9 & 55.9 \\
47 & Chronic glomerulonephritis & 61.4 & 63.3 \\
48 & Nephrosis & 50.8 & 50.8 \\
54 & Malignant hypertension & 66.0 & 67.8 \\
58 & Malignant hypertension & 62.6 & 62.6 \\
59 & Focal nephritis & 67.0 & 74.0 \\
68 & Focal nephritis & 71.6 & 67.3 \\
69 & Arteriosclerosis & 69.6 & 67.8 \\
71 & & 69.6 \\
\hline
\end{tabular}




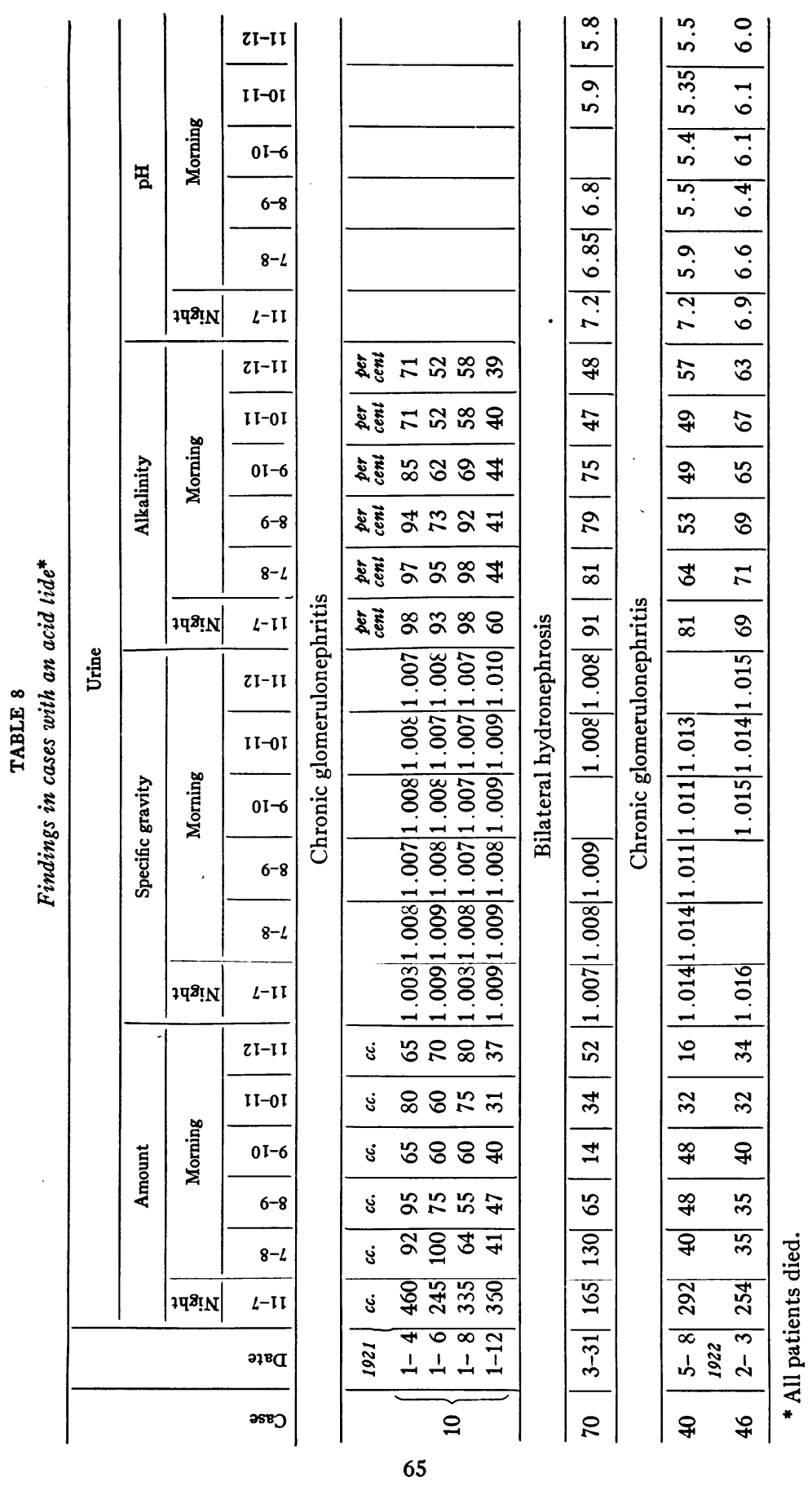

THE JOURNAL OF CLINICAL INVESTIGATION, VOL. II, NO. 1 


\section{BIBLIOGRAPHY}

1. Bell, R. D., and Doisy, E. A.: Jour. Biol. Chem., 1920, xliv, 55. Rapid Colorimetric Methods for the Determination of Phosphorus in Urine and Blood.

2. Clark, W. M.: The Determination of Hydrogen Ions. 2 ed. Baltimore, 1923.

3. Fiske, C. H.: Jour. Biol.. Chem., 1921, xlix, 171. Inorganic Phosphate and Acid Excretion in the Postabsorptive Period.

4. Gamble, J. L.: Jour. Biol. Chem., 1922, li, 295. Carbonic Acid and Bicarbonate in Urine.

5. Henderson, L. J., and Palmer, W. W.: Jour. Biol. Chem., 1912-1913, xiii, 393. On the Intensity of Urinary Acidity in Normal and Pathological Conditions.

6. Henderson, L. J., and Palmer, W. W.: Jour. Biol. Chem., 1913, xiv, 81. On the Extremes of Variation of the Concentration of Ionized Hydrogen in Human Urine.

7. Leathes, J. B.: Brit. Med. Jour., 1919, ii, 165. Renal Efficiency Tests in Nephritis and the Reaction of the Urine.

8. Marshall, E. K., Jr.: Jour. Biol. Chem., 1922, li, 3. The Effect of Loss of Carbon Dioxide on the Hydrogen Ion Concentration of Urine.

9. Van Slyke, D. D.: Jour. Biol. Chem., 1917, xxx, 347. Studies of Acidosis. II. A Method for the Determination of Carbon Dioxide and Carbonates in Solution. 